\title{
Hubungan Pemerintah Pusat dengan Pemerintah Daerah dalam Kerangka Pengelolaan Keuangan Negara dan Daerah
}

\author{
Telly Sumbu \\ Fakultas Hukum Universitas Sam Ratulangi Manado \\ Jl. Kampus Unsrat Bahu Manado 95115 \\ priscaoktavia@yahoo.com
}

\begin{abstract}
The state and district financial management is an important part in the governmental arrangement in Indonesia. To decide the problem of state and district financial status, it should be placed in the context of constitutional and governmental system which is followed in Indonesia. The problem that would like to be investigated is how is the relation between the central government and district government in the frame of state and district financial management. This research used the investigation of normative law. The approach method used was jurisdiction. The data compiling is conducted through literacy study. In this research, the compiled material would be qualitatively analyzed. The result of this research has concluded that the basic law in applied the state and district financial management is different. However, both are still in an inseparable relation since both are conducted in the frame of Negara Kesatuan Republik Indonesia (United nation of Indonesia Republic).
\end{abstract}

Key words: State finance, district finance.

\begin{abstract}
Abstrak
Pengelolaan keuangan negara dan daerah merupakan bagian penting dalam penyelenggaraan pemerintahan di Indonesia. Untuk menentukan masalah kedudukan keuangan negara dan keuangan daerah seharusnya diletakkan dalam konteks ketatanegaraan dan sistem pemerintahan yang dianut di Indonesia. Permasalahan yang hendak diteliti adalah bagaimana hubungan Pemerintah Pusat dengan Pemerintah Daerah dalam kerangka pengelolaan keuangan negara dan keuangan daerah. Penelitian ini menggunakan jenis penelitian hukum normatif. Metode pendekatan yang digunakan adalah yuridis. Pengumpulan data dilakukan melalui studi pustaka. Dalam penelitian ini, bahan-bahan yang terkumpul akan dianalisis secara kualitatif. Hasil penelitian menyimpulkan bahwa dasar hukum pelaksanaan pengelolaan keuangan negara dan keuangan daerah memang berbeda namun keduanya tetap berada dalam suatu hubungan tidak terpisahkan karena keduanya dilaksanakan dalam kerangka Negara Kesatuan Republik Indonesia.
\end{abstract}

Kata kunci : Keuangan negara, keuangan daerah 


\section{Pendahuluan}

Tujuan negara sebagaimana tercantum dalam Alinea IV Pembukaan UndangUndang Dasar Negara Republik Indonesia Tahun 1945 (UUD 1945), yaitu melindungi segenap bangsa Indonesia dan seluruh tumpah darah Indonesia, dan untuk memajukan kesejahteraan umum, mencerdaskan kehidupan bangsa dan ikut melaksanakan ketertiban dunia.

Pembentukan suatu pemerintah Negara Republik Indonesia sebagaimana disebutkan dalam UUD 1945 tersebut menimbulkan hak dan kewajiban negara yang dapat dinilai dengan uang yang perlu dikelola dalam suatu sistem pengelolaan keuangan negara yang kuat. Sebagai konsekuensi pelaksanaan hak dan kewajibankewajiban tersebut, pemerintah memerlukan dana yang cukup, yang harus disediakan dalam Anggaran Pendapatan dan Belanja Negara (APBN). Untuk mencapai hasil yang diharapkan seperti dikemukakan di atas, diperlukan sebuah sistem pengelolaan keuangan negara yang harus sesuai dengan konstitusi (UUD 1945) untuk menjaga kelangsungan kedaulatan negara dan meningkatkan kemakmuran masyarakat yang berkedaulatan rakyat dan berdasarkan atas hukum.

Dalam Bab VIII Hal Keuangan, UUD 1945, antara lain disebutkan dalam Pasal 23 ayat (1) bahwa APBN sebagai wujud dari pengelolaan keuangan negara setiap tahun ditetapkan dengan undang-undang dan dilaksanakan secara terbuka dan bertanggung jawab untuk sebesar-besarnya kemakmuran rakyat. Pasal 23 A yang mengatur bahwa pajak dan pungutan lain yang bersifat memaksa untuk keperluan negara diatur dengan undang-undang. Hal-hal lain mengenai keuangan negara sesuai dengan amanat Pasal $23 \mathrm{C}$ diatur dengan undang-undang.

Upaya untuk menyusun undang-undang yang mengatur pengelolaan keuangan negara yang pada dasarnya telah dirintis sejak awal berdirinya negara Indonesia. Sehingga dapat dikatakan bahwa penyelesaian undang-undang tentang keuangan negara merupakan kelanjutan dan hasil dari berbagai upaya yang telah dilakukan selama ini dalam rangka memenuhi kewajiban konstitusional yang diamanatkan oleh UUD 1945.

Secara resmi Dewan Perwakilan Rakyat (DPR) telah mengesahkan Rancangan Undang-Undang (RUU) tentang keuangan negara menjadi Undang-undang No. 17 Tahun 2003 tentang Keuangan Negara. Hal-hal dan/ atau perubahan mendasar dalam ketentuan keuangan negara yang diatur dalam undang-undang ini meliputi 
pengertian dan ruang lingkup keuangan negara, asas-asas umum pengelolaan keuangan negara, kedudukan Presiden sebagai pemegang kekuasaan pengelolaan keuangan negara, pendelegasian kekuasaan Presiden kepada Menteri Keuangan dan Menteri/Pimpinan Lembaga, susunan APBN dan APBD, ketentuan mengenai penyusunan dan penetapan APBN dan APBD, penetapan bentuk dan batas waktu penyampaian laporan pertanggungjawaban pelaksanaan APBN dan APBD.

Undang-Undang Keuangan Negara diharapkan menjadi pedoman umum tentang pengelolaan keuangan negara dalam setiap tingkatan pemerintahan, baik pusat maupun daerah, serta berbagai unit pemerintahan lainnya, baik di pusat maupun di daerah, yang meliputi departemen, lembaga non departemen dan badan usaha milik negara/daerah. Lebih daripada itu, Undang-Undang Keuangan Negara diharapkan dapat menunjukkan keterkaitan sistem keuangan antar setiap elemen/ komponen yang terlibat dalam pengelolaan keuangan negara tersebut.

Upaya untuk mewujudkan sistem pengelolaan keuangan negara/daerah yang tertib, efektif dan efisien, pemerintah telah mengundangkan paket perundangundangan bidang keuangan negara setelah diterbitkannya Undang-Undang Nomor 17 Tahun 2003 . Paket perundang-undangan yang dimaksud adalah Undang-Undang Nomor 1 Tahun 2004 tentang Perbendaharaan Negara dan Undang-Undang Nomor 15 Tahun 2004 tentang Pemeriksaan Pengelolaan dan Tanggung Jawab Keuangan Negara, Peraturan Pemerintah Nomor 58 Tahun 2005 tentang Pengelolaan Keuangan Daerah.

Arifin P. Soeria Atmadja ${ }^{1}$ mengemukakan bahwa 5 April 2003 pelaksanaan pengelolaan keuangan negara masih didasarkan pada aturan kolonial Hindia Belanda yang berlaku berdasarkan aturan peralihan UUD 1945, yaitu Indische Comptabiliteitswet yang lebih dikenal dengan nama ICW, Indische Bedrijvenwet (IBW) dan Reglement voor het Administratief Beheer (RAB). Peraturan perundangan tersebut dipandang tidak dapat mengakomodasi berbagai perkembangan yang terjadi dalam sistem kelembagaan negara dan pengelolaan keuangan negara. Oleh karena itu, meskipun berbagai ketentuan tersebut secara formal masih tetap berlaku, secara materiil sebagian dari ketentuan perundangan tersebut tidak lagi dilaksanakan. ${ }^{2}$

\footnotetext{
${ }^{1}$ Arifin P. Soeria Atmadja, Hukum Kenangan Negara Pasca 60 Tahun Indonesia Merdeka, tanpa tahun, www. Pemantauperadilan.com, akses tanggal 2 Desember 2009, hlm. 4-5.

${ }^{2}$ Ibid., hlm. 4
} 
Ruang lingkup keuangan negara menurut Undang-Undang Nomor 17 Tahun 2003 meliputi: a. Hak negara untuk memungut pajak, mengeluarkan dan mengedarkan uang, dan melakukan pinjaman; b. Kewajiban negara untuk menyelenggarakan tugas layanan umum pemerintahan negara dan membayar tagihan pihak ketiga; c. Penerimaan Negara; d. Pengeluaran Negara; e. Penerimaan Daerah; f. Pengeluaran Daerah; g. Kekayaan negara/kekayaan daerah yang dikelola sendiri atau oleh pihak lain berupa uang, surat berharga, piutang, barang, serta hak-hak lain yang dapat dinilai dengan uang, termasuk kekayaan yang dipisahkan pada perusahaan negara atau daerah; h. Kekayaan pihak lain yang dikuasai oleh pemerintah dalam rangka penyelenggaraan tugas pemerintahan dan/atau kepentingan umum; i. Kekayaan pihak lain yang diperoleh dengan menggunakan fasilitas yang diberikan pemerintah.

UU Keuangan Negara secara tegas menyebutkan bahwa keuangan daerah merupakan bagian dari keuangan negara. Terbitnya Undang-Undang No. 17 Tahun 2003 merupakan produk reformis di bidang keuangan negara. Isi dan maksud pokok dari undang-undang ini antara lain menyatukan pengaturan dua sistem dalam keuangan negara, yakni sistem pengelolaan keuangan negara dan sistem pengelolaan keuangan daerah. Namun jika ditelaah secara mendalam latar belakang dan tujuan penyatuan tersebut tidak ditemukan dalam UU No. 17 Tahun 2003. ${ }^{3}$

Dalam Undang-undang ini tidak ditemukan pengertian dari keuangan daerah, tetapi istilahnya ada dimuat dalam undang-undang ini. Bahkan lebih tidak selaras lagi (disharmoni) dalam Undang-Undang No. 15 Tahun 2004 tentang Pemeriksaan Pengelolaan dan Tanggungjawab Keuangan Negara, tidak ditemukan istilah keuangan daerah, pada hal keuangan daerah ini merupakan obyek pemeriksaan Badan Pemeriksa Keuangan (BPK).

Reformasi di bidang keuangan negara seperti terbitnya UU No. 17 Tahun 2003 dan undang-undang lainnya termasuk pengaturan sistem pengelolaan keuangan daerah yang telah dilekatkan di dalam sistem keuangan negara. Reformasi di bidang keuangan negara membawa dampak yang serius, yakni kebaradaan keuangan daerah dalam sistem keuangan negara, seperti tidak dimuatnya pengertian, lingkup dan hubungannya dengan keuangan negara. Akibat ketidakselarasan pengertian ini dapat berdampak juga pada sistem dan kewenangan pemeriksaan keuangan negara yang dilakukan oleh BPK. ${ }^{4}$

\footnotetext{
${ }^{3}$ Ghandi, L.M., "Harmonisasi Hukum Menuju Hukum Responsif”, Pidato Pengukuhan Jabatan Guru Besar Tetap pada Fakultas Hukum Universitas Indonesia, Jakarta, 1995, hlm. 7.

${ }^{4}$ Arifin P. Soeria Atmadja, Hukum Kenangan Negara..., Loc. Cit.
} 
Disharmonisasi pengaturan keuangan negara yang singkat dalam UUD 1945 dikemukakan oleh Arifin P. Soeria Atmadja membawa masalah yuridis terhadap defenisi keuangan negara, sehingga membuka penafsiran yang berbeda-beda terhadap defenisi tersebut. ${ }^{5}$

Namun dalam kerangka teoritis hukum keuangan negara, berdasarkan penafsiran Pasal 23 ayat (1) UUD 1945 jo. Pasal 23 ayat (5) UUD 1945 yang dimaksud sebagai keuangan negara adalah yang ditetapkan dalam Undang-Undang APBN. Dengan dasar penafsiran itu Arifin P. Soeria Atmadja menyimpulkan secara tegas maksud keuangan negara sebagai APBN, yang kemudian menjadi dasar pemeriksaan BPK dalam memeriksa keuangan negara. Hal ini berarti keuangan lain di luar APBN tidak dapat dikategorikan sebagai keuangan negara.

\section{Rumusan Masalah}

Berdasarkan uraian di atas, permasalahan yang ingin diteliti dalam penelitian ini adalah bagaimana hubungan Pemerintah Pusat dengan Pemerintah Daerah dalam kerangka pengelolaan keuangan negara dan keuangan daerah.

\section{Tujuan Penelitian}

Penelitian ini bertujuan untuk mengetahui dan menganalisis hubungan Pemerintah Pusat dan Pemerintah Daerah dalam kerangka pengelolaan keuangan negara dan keuangan daerah.

\section{Metode Penelitian}

Penelitian ini menggunakan jenis penelitian hukum normatif, yang akan mengkaji hubungan Pemerintah Pusat dan Pemerintah Daerah dalam pengelolaan keuangan negara dan keuangan daerah. Karena penelitian ini merupakan penelitian normatif yang berupa studi pustaka, maka data dalam penelitian ini adalah data yang diperoleh dari studi pustaka yang akan menghasilkan bahan hukum primer dan sekunder. 
Bahan hukum primer berupa peraturan perundang-undangan yang terkait dengan permasalahan yang diteliti, terutama UUD 1945, UU No. 17 Tahun 2003 tentang Keuangan Negara, UU No. 15 Tahun 2004 tentang Pemeriksaan Pengelolaan dan Tanggungjawab Keuangan Negara, UU No. 32 Tahun 2004 tentang Pemerintahan Daerah, dan Peraturan Pemerintah Nomor 58 Tahun 2005 tentang Pengelolaan Keuangan Daerah.

Bahan hukum berupa buku-buku literatur, disertasi, jurnal yang relevan, risalahrisalah sidang DPR, tulisan-tulisan ilmiah, hasil-hasil seminar, penelitian terdahulu, internet, artikel, dan lain-lain.

Metode pendekatan yang digunakan adalah yuridis. Pengumpulan bahan hukum dilakukan melalui studi pustaka. Dalam penelitian ini, bahan-bahan yang terkumpul akan dianalisis secara kualitatif.

\section{Hasil dan Pembahasan}

\section{Keuangan Negara}

Dalam Pasal 1 UU No. 17 Tahun 2003 ditegaskan bahwa Keuangan Negara adalah semua hak dan kewajiban negara yang dapat dinilai dengan uang, serta segala sesuatu baik berupa uang maupun berupa barang yang dapat dijadikan milik negara berhubung dengan pelaksanaan hak dan kewajiban tersebut. Ada beberapa pendapat terkait dengan definisi keuangan negara. Pendapat dimaksud antara lain:

Pertama, M. Ichwan ${ }^{6}$ mengemukakan bahwa keuangan negara adalah rencana kegiatan secara kuantitatif (dengan angka-angka di antaranya diwujudkan dalam jumlah mata uang), yang akan dijalankan untuk masa mendatang, lazimnya satu tahun mendatang.

Kedua, Geodhart ${ }^{7}$ mengemukakan bahwa keuangan negara merupakan keseluruhan undang-undang yang ditetapkan secara periodik yang memberikan kekuasaan pemerintah untuk melaksanakan pengeluaran mengenai periode tertentu dan menunjukkan pembiayaan yang diperlukan untuk menutup pengeluaran tersebut. Unsur-unsur keuangan negara menurut Geodhart meliputi : 1. periodik; 2.

\footnotetext{
${ }^{6}$ W. Riawan Tjandra, Hukum Keuangan Negara, PT Grasindo, Jakarta, 2006, hlm. 1.

${ }^{7}$ I Gde Artjana, "Upaya Membangun Akuntabilitas Pengelolaan Dan Pertanggungjawaban Keuangan Negara Di Lingkungan Militer Menuju Terciptanya Good Governance Tantangan Dan Harapan”, dipaparkan dalam FGD SSR Propatria, tanggal 27 Februari 2007.
} 
pemerintah sebagai pelaksana anggaran; 3. pelaksanaan anggaran mencakup dua wewenang, yaitu wewenang pengeluaran dan wewenang untuk menggali sumbersumber pembiayaan untuk menutup pengeluaran-pengeluaran yang bersangkutan; dan 4 . bentuk anggaran negara adalah berupa suatu undang-undang.

Ketiga, Glenn A. Welsch ${ }^{8}$ mengemukakan bahwa budget adalah suatu bentuk statement dari rencana dan kebijaksanaan manajemen yang dipakai dalam suatu periode tertentu sebagai petunjuk atau blue print dalam periode itu.

Keempat, John F. Due ${ }^{9}$ mengemukakan bahwa Budget adalah suatu rencana keuangan untuk suatu periode waktu tertentu. Government budget (anggaran belanja pemerintah) adalah suatu pernyataan megenai pengeluaran atau belanja yang diusulkan dan penerimaan untuk masa mendatang bersama dengan data pengeluaran dan penerimaan yang sebenarnya untuk periode mendatang dan periode yang telah lampau. Unsur-unsur definisi John F. Due menyangkut hal-hal berikut: 1. anggaran belanja yang memuat data keuangan mengenai pengeluaran dan penerimaan dari tahun-tahun yang sudah lalu; 2. jumlah yang diusulkan untuk tahun yang akan datang; 3. jumlah taksiran untut tahun yang sedang berjalan; 4. rencana keuangan tersebut untuk suatu peride tertentu.

Kelima, Otto Ekstein ${ }^{10}$ mengemukakan bahwa anggaran belanja adalah suatu pernyataan rinci tentang pengeluaran dan penerimaan pemerintah untuk waktu satu tahun.

Keenam, Van der Kemp ${ }^{11}$ mengemukakan bahwa keuangan negara adalah semua hak yang dapat dinilai dengan uang. Demikian pula segala sesuatu (baik berupa uang ataupun barang) yang dapat dijadikan milik negara berhubungan dengan hak-hak tersebut.

Pengertian-pengertian keuangan negara seperti tersebut di atas menjelaskan pula mengenai lingkup keuangan negara. Terkait dengan pengertian keuangan negara, Riawan Tjandra ${ }^{12}$ mengemukakan : “Untuk lebih memahami pengertian keuangan negara, terlebih dahulu perlu dipahami mengenai pengertian keuangan. Secara umum keuangan diartikan sebagai segala aktivitas yang bertalian dengan pembayaran uang. Pembayaran itu dimungkinkan apabila ada penerimaan terlebih

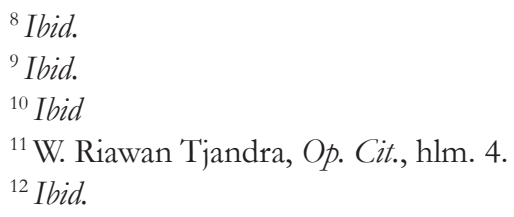


dahulu. Oleh karena itu keuangan sering diartikan sebagai suatu sistem mengenai penerimaan dan pengeluaran uang."

Bertolak dari alasan-alasan ini, yang dimaksud keuangan negara adalah semua hal yang bertalian dengan masalah penerimaan dan pengeluaran dari suatu negara. Jadi secara umum dapat dikatakan bahwa pengelolaan keuangan negara adalah keseluruhan kegiatan pejabat pengelola keuangan negara sesuai dengan kedudukan dan kewenangannya, yang meliputi perencanaan, pelaksanaan, pengawasan, dan pertanggungjawaban. ${ }^{13}$

Dalam keuangan negara juga telah diatur secara jelas hubungan kewenangan dalam pengelolaan keuangan negara. Presiden berkedudukan sebagai pemegang kekuasaan pengelolaan keuangan negara. Kekuasaan tersebut dibantu oleh Menteri Keuangan, menteri/pimpinan lembaga dan bank sentral.

Fungsi anggaran negara berdasarkan kajian hukum tata negara adalah perpaduan kedaulatan rakyat, pemerintah dan DPR di mana pemerintah pada hakikatnya merupakan pelaksanaan kedaulatan rakyat di bidang pemerintahan negara sehingga berwenang mengajukan perancangan anggaran, DPR merupakan pelaksanaan kedaulatan rakyat di bidang legislatif khususnya bidang anggaran. ${ }^{14}$

Pengurusan terhadap keuangan negara terdiri atas pengurusan umum dan pengurusan khusus. Dalam pengurusan umum, pejabat yang melaksanakan pengurusan anggaran negara dapat diklasifikasikan atas dua macam, yaitu seperti berikut :15

Pertama, otorisator adalah pejabat yang mempunyai wewenang untuk mengambil tindakan/keputusan yang dapat mengakibatkan uang negara keluar sehingga menjadi berkurang atau bertambah karena pungutan dari masyarakat. Wewenang untuk mengambil keputusan yang dapat mengakibatkan uang negara berkurang atau bertambah disebut otorisasi. Otorisasi dapat diklasifikasikan menjadi dua macam, yaitu : a. Otorisasi umum: otorisasi yang berupa keputusan dan tindakan yang lazimnya berbentuk peraturan umum. Contohnya: peraturan pensiun dan UU Pajak. b. Otorisasi yang berbentuk surat keputusan yang khususnya mengikat orang/ pihak tertentu, misalnya surat keputusan pegawai negeri dan otorisasi untuk proyek.

\footnotetext{
${ }^{13}$ Herlambang Perdana Wiratraman, Badan Pemeriksa Keuangan dan Pertanggungjawaban Keuangan Negara, Departemen Hukum Tata Negara Fakultas Hukum Universitas Airlangga, Surabaya, 2008, hlm. 6.

${ }^{14}$ Muhammad Djafar Saidi, Hukum Kenangan Negara, Rajawali Press, Jakarta, 2008, hlm. 106.

${ }^{15}$ Soebagyo, Ibid., hlm. 17
} 
Kedua, ordonator adalah pejabat yang melakukan pengawasan terhadap otorisator agar otorisator tersebut dalam melaksanakan tindakan/keputusannya selalu demi kepentingan umum. Tugas utama ordonator adalah melaksanakan pengujian dan penelitian terhadap penerimaan maupun pengeluaran uang negara. Oleh karena itu, ordonator dibedakan sebagai berikut: a. Ordonator pengeluaran negara. Ordonator pengeluaran negara adalah pejabat yang dalam hal ini ditunjuk Menteri Keuangan dan sebagai pelaksana adalah Direktorat Jenderal Anggaran, yang untuk daerah dilaksanakan oleh kantor perbendaharaan negara. Tugas ordonator pengeluaran negara ialah: (1) Melakukan penelitian dan pengujian terhadap : (a) Bukti-bukti penagihan, artinya apakah kuitansi/berita acara serah terima barang maupun kontrak perjanjian sudah sesuai dengan peraturan yang berlaku, dan (b) apakah bukti-bukti itu kadaluwarsa. (2) Membukukan pada pos mata anggaran yang tepat artinya membukukan pengeluaran uang negara tersebut pada pos mata anggaran yang sesuai dengan tujuan pengeluaran. (3) Memerintahkan membayar uang, hal ini dilakukan dengan menerbitkan Surat Perintah Membayar (selanjutnya disebut SPM). Pengeluaran yang diperintahkan oleh ordonator ada dua macam, yaitu: (1) pengeluaran negara dengan beban total, artinya pengeluaran negara yang bukti penagihannya telah diajukan terlebih dahulu kepada ordonator untuk diperiksa sehingga dapat dibukukan kepada pos mata anggaran yang tetap; (2) pengeluaran negara dengan beban sementara, artinya uang dikeluarkan tanpa bukti penagihannya dikeluarkan terlebih dahulu sehingga oleh ordonator dibukukan pada pos mata anggaran sementara. Pembukuan sementara ini berubah sifatnya menjadi pembukuan dengan beban tetap setelah bukti penagihannya dikirimkan kepada ordonator atau setelah ordonator menerima Surat Pertanggungjawaban (selanjutnya disebut SPJ). b. Ordonator penerimaan negara. Pelaksana ordonator penerimaan negara adalah semua menteri yang menguasai pendapatan negara. Tugas utamanya ialah mengawasi apakah penerimaan negara tersebut sesuai dengan peraturan yang berlaku atau tidak. la juga mengeluarkan surat keputusan yang mengakibatkan penerimaan bagi negara. Atas dasar surat keputusan ini juga diterbitkan Surat Perintah Membayar (SPM).

Dalam pengurusan khusus, yang ditunjuk untuk menjalankan pengurusan itu adalah bendaharawan, yang dibebani tugas pengurusan dan penyimpanan sebagian dari kekayaan negara berupa uang dan barang. Dalam praktik, tugas pengurusan uang diwujudkan dalam penerimaan, penyimpanan, dan pembayaran atas perintah 
ordonator. Pengurusan barang meliputi penerimaan, penyimpanan, pengeluaran (penyerahan), dan pemeliharaannya. Bendaharawan dapat ditinjau dari dua segi, seperti di bawah ini:

Pertama, ditinjau dari objeknya, yaitu a. Bendaharawan uang, yaitu objek pengurusannya adalah uang negara; b. Bendaharawan barang, yaitu objek pengurusannya barang milik negara; c. Bendaharawan uang dan barang, yang objek pengurusannya baik uang maupun barang.

Kedua, ditinjau dari sudut tugasnya bendaharawan umum dan bendaharawan khusus. a. Bendaharawan umum, adalah bendaharawan yang mempunyai tugas untuk menerima pendapatan negara yang terkumpul dari masyarakat, kemudian dari persediaan yang ada akan dikeluarkannya lagi untuk kepentingan umum. Contohnya, kepala kas negara, Bank Indonesia, kepala kantor pos dan bank lain yang ditunjuk Menteri Keuangan. b. Bendaharawan khusus adalah bendaharawan yang mengurus pengeluaran negara dari persediaan uang yang ada padanya dan diterima dari bendaharawan umum. Untuk itu ia diharuskan membuat pertanggungjawaban atas pengeluaran yang telah dilakukannya dengan mengirimkan surat pertanggungjawaban (SPJ) yang dibuat tiap-tiap bulan.

\section{Keuangan Daerah}

Pendekatan dalam memahami ruang lingkup keuangan daerah dapat dipandang dari sisi objek, subjek, proses dan tujuannya ${ }^{16}$ yaitu: Pertama, dari sisi objek, yang dimaksud keuangan daerah adalah semua hak dan kewajiban daerah dalam rangka penyelenggaraan pemerintah daerah yang dapat dinilai dengan uang termasuk didalamnya segala bentuk kekayaan yang berhubungan dengan hak dan kewajiban daerah, dalam kerangka APBD. Pengertian ini sejalan dengan pengertian yang diberikan dalam Penjelasan Pasal 156 ayat (1) Undang-Undang Nomor 32 Tahun 2004 tentang Pemerintahan Daerah yang lengkapnya berbunyi sebagai berikut : Semua hak dan kewajiban daerah dalam rangka penyelenggaraan pemerintah daerah yang dapat dinilai dengan uang, dan segala berupa uang dan barang yang dapat dijadikan milik daerah yang berhubungan dengan pelaksanaan hak dan kewajiban tersebut.

Kedua, dari sisi subjek, subjek keuangan daerah adalah mereka yang terlibat dalam pengelolaan keuangan daerah dalam hal ini pemerintah daerah dan perangkatnya,

${ }^{16}$ Muhammad Djumhana, Pengantar Hukum Keuangan Daerah, Citra Aditya Bhaktim, Bandung, 2007, hlm. 1. 
perusahaan daerah, dan badan lain yang ada kaitannya dengan keuangan daerah, seperti DPRD dan Badan Pemeriksa Keuangan (selanjutnya disebut BPK). Ketiga, dari sisi proses, keuangan daerah mencakup seluruh rangkaian kegiatan yang berkaitan dengan pengelolaan objek mulai dari perumusan kebijakan sampai dengan pertanggungjawaban. Keempat, dari sisi tujuan, keuangan daerah meliputi keseluruhan kebijakan, kegiatan dan hubungan hukum yang berkaitan dengan pemilikan dan/ atau penguasaan objek dalam rangka penyelenggaraan pemerintahan daerah.

Dari gambaran objek, subjek, proses dan tujuan tersebut di atas pada dasarnya berada pada satu kegiatan yang disebut dengan pengelolaan keuangan daerah. Pengelolaan dimaksud mencakup keseluruhan kegiatan perencanaan, penguasaan, penggunaan, pengawasan dan pertanggungjawaban. Dalam menjalankan pengelolaan tersebut dikenal adanya kekuasaan pengelola. Pemegang kekuasaan mengelola keuangan di daerah adalah gubernur/bupati atau walikota selaku kepala pemerintahan daerah. ${ }^{17}$

Pelaksanaan kekuasaan atas pengelolaan keuangan daerah tersebut kemudian dilaksanakan oleh dua komponen yaitu Kepala Satuan Kerja Pengelolaan Keuangan Daerah selaku pejabat pengelola APBN dan Kepala SKPD selaku Pejabat Pengguna Anggaran/Barang Negara. ${ }^{18}$

Dari ruang lingkup keuangan daerah, sebagaimana diuraikan di atas, maka akan selalu melekat dengan konsep anggaran teruatma terkait dengan APBD yaitu suatu rencana keuangan tahunan daerah yang ditetapkan berdasarkan peraturan daerah. Rencana pemerintah daerah sebagaimana tertuang dalam APBD merupakan salah satu bentuk instrumen kebijakan ekonomi, yang mempunyai fungsi tersendiri yaitu: ${ }^{19}$

Pertama, Fungsi Otorisasi. Mengandung pengertian bahwa anggaran menjadi dasar untuk melaksanakan pendapatan dan belanja pada tahun yang bersangkutan. Kedua, Fungsi Perencanaan. Mengandung arti bahwa anggaran menjadi pedoman bagi manajemen dalam merencanakan kegiatan pada tahun yang bersangkutan. Ketiga, Fungsi Pengawasan. Mengandung arti bahwa anggaran menjadi pedoman untuk menilai apakah kegiatan penyelenggaraan pemerintahan sesuai dengan ketentuan yang telah ditetapkan. Keempat, Fungsi Alokasi. Mengandung arti bahwa anggaran harus diarahkan untuk mengurangi pengangguran dan pemborosan sumber daya

\footnotetext{
${ }^{17}$ Pasal 6 ayat (2) UU Nomor 17 Tahun 2003 tentang Keuangan Negara

${ }^{18}$ Pasal 10 ayat (1) UU Nomor 17 Tahun 2003 tentang Keuangan Negara

${ }^{19}$ Muhammad Djumhana, Op. Cit.. hlm. 3.
} 
serta meningkatkan efisiensi dan efektivitas perekonomian. Kelima, Fungsi Distribusi. Mengandung arti bahwa kebijakan anggaran harus memperhatikan rasa keadilan dan kepatutan. Keenam, Fungsi Stabilisasi. Mengandung arti bahwa anggaran pemerintah menjadi alat untuk memelihara dan menngupayakan keseimbangan fundamental perekonomian. Selain berkaitan erat dengan APBD dalam keuangan daerah tersebut melekat 4 (empat) dimensi : 1. Adanya dimensi hak dan kewajiban; 2 . Adanya dimensi tujuan dan perencanaan; 3 . Adanya dimensi penyelenggaraan dan pelayanan publik; dan 4. Adanya dimensi nilai uang dan barang (investasi dan inventarisasi).

Keempat dimensi di atas menyangkut aspek penyusunan anggaran, pelaksanaan anggaran, dan aspek pertanggungjawaban anggaran. Semua itu diatur dalam Bab VIII dari Pasal 155-194 Undang-Undang Nomor 32 Tahun 2004.

\section{Sistem Pemerintahan Indonesia}

Istilah pemerintah berasal dari kata "perintah" yang berarti menyuruh melakukan sesuatu sehingga dapat dikatakan bahwa pemerintah adalah kekuasaan memerintah sesuatu negara (daerah negara) atau badan tertinggi yang memerintah suatu negara seperti kabinet yang merupakan suatu pemerintah. Jadi, pemerintahan diartikan sebagai perbuatan (cara, hal urusan dan sebagainya) memerintah. ${ }^{20}$

Secara etimologis pemerintahan dapat pula diartikan sebagai tindakan yang terus menerus (kontinu) atau kebijaksanaan yang menggunakan suatu rencana maupun akal (rasio) dan tata cara tertentu untuk mencapai suatu tujuan tertentu yang dikehendaki. ${ }^{21}$

Ada pula pakar yang menganggap bahwa pemerintahan adalah suatu ilmu seni. Disebut sebagai ilmu karena memenuhi syarat-syaratnya yaitu dapat dipelajari dan diajarkan, memiliki objek material dan formal, universal, sistematis dan khas (spesifik) dan dikatakan sebagai seni karena banyak pemimpin pemerintahan yang tanpa pendidikan pemerintahan, mampu berkiat serta dengan kharismatik menjalankan roda pemerintahan. ${ }^{22}$

Dalam kata perintah ada dua pihak yang terkandung dan memiliki hubungan yaitu pihak yang memerintah yang memiliki wewenang dan pihak yang diperintah

\footnotetext{
${ }^{20}$ Soemantri dalam Pipin Syarifin dan Dedah Subaedah, Hukum Pemerintahan Daerah, Pustaka Bani Quraisy, Bandung, 2005, hlm. 63.

${ }^{21}$ Utrecht, Pengantar Hukum Indonesia, Ichtiar Baru, Jakarta, 1986, hlm. 28.

${ }^{22}$ Inu Kencana Syafii, Sistem Pemerintahan Indonesia, Rineka Cipta, Jakarta, 2002, hlm. 11.
} 
yang memiliki ketaatan. Jadi pemerintah dengan pemerintahan memiliki arti yang berbeda. Pemerintah adalah jawatan atau aparatur dalam susunan politik sedangkan pemerintahan adalah tugas kewajiban alat negara. Istilah penguasa dipakai pula untuk mewakili istilah "pemerintahlah yang berkuasa". ${ }^{23}$

The Liang $\mathrm{Gie}^{24}$ menyatakan bahwa untuk menghindarkan keraguan dalam memberikan pembatasan pengertian maka untuk istilah pemerintah menunjuk pada organnya sedangkan untuk istilah pemerintahan menunjuk pada fungsinya. Dalam praktiknya, ada dua pengertian tentang pemerintah yaitu pemerintah dalam arti luas dan pemerintah dalam arti sempit.

Pengertian pemerintah dalam arti luas ${ }^{25}$ adalah pengertian pemerintah yang didasarkan pada teori klasik yang dikemukakan oleh Montesqieu dalam bukunya "L'espirit des Lois" (jiwa undang-undang) yang dikembangkan oleh Immanuel Kant dengan sebutan trias politica yang membagi kekuasaan negara (membagi tugas pemerintahan) dalam tiga bidang kekuasaan negara dalam tiga bidang pokok yang masing-masing berdiri sendiri, lepas dari kekuasaan lainnya. Satu kekuasaan hanya mempunyai 1 (satu) fungsi saja : 1. Kekuasaan legislatif menjalankan fungsi membentuk undang-undang; 2. Kekuasaan eksekutif menjalankan undang-undang/ pemerintahan; dan 3. Kekuasaan yudikatif menjalankan fungsi peradilan

Pendapat lain sehubungan dengan arti pemerintah secara luas juga dikemukakan oleh van Vollenhoven yang menambahkan bagian ke 4 yaitu kepolisian pada pembagian dari Montesqieu. Pembagian kekuasaan yang disebut Tri Praja dari Montesqieu dan ajaran Catur Praja dari Van Vallenhoven jika digabungkan maka kewenangan pemerintahan dalam arti luas adalah: ${ }^{26} 1$. Membentuk perundangundangan sendiri (zelfwetgeving); 2. Melaksanakan pemerintahan sendiri (zelf uitooering); 3. Melaksanakan peradilan sendiri (zelfrechtspraak); 4. Melaksanakan tugas kepolisian sendiri (zelf politie).

Menurut Bagir Manan dan Kuntana Magnar ${ }^{27}$ bahwa pemerintahan dalam arti luas ialah mencakup semua alat kelengkapan negara yang pada pokoknya terdiri

\footnotetext{
${ }^{23}$ Muhammad Yamin, Proklamasi dan Konstitusi, Ghalia Indonesia, Jakarta, 1982, hlm. 112.

${ }^{24}$ The Liang Gie, Pertumbuban Pemerintahan Daerah di Negara Republik Indonesia, Liberty, Yogyakarta, 1993, hlm. 32.

${ }^{25}$ Ismail Suny dalam Pipin Syarifin dan Dedah Subaedah, Op. Cit., 2005, hlm. 65.

${ }^{26}$ Amrah Muslimin, Aspek-Aspek. Otonomi Daerah, Alumni, Bandung, 1986, hlm. 45.

${ }^{27}$ Bagir Manan dan Kuntana Magnar, Peranan Peraturan Perundang-Undangan dalam Pembinaan Hukum Nasional, Armico, Bandung, 1997, hlm. 158.
} 
dari cabang-cabang kekuasaan eksekutif, legislatif, dan yudisial atau alat-alat kelengkapan negara lain yang juga bertindak untuk dan atas nama negara.

Dari pendapat beberapa pakar di atas dapat dikatakan bahwa yang dimaksud dengan pemerintahan dalam arti luas adalah semua aparatur/alat kelengkapan negara dalam rangka menjalankan segala tugas dan kewenangan/kekuasaan negara baik kekuasaan legislatif, eksekutif, dan kekuasaan yudikatif sedangkan pengertian pemerintahan dalam arti sempit adalah aparatur pemerintahan yang hanya mempunyai tugas dan kewenangan eksekutif saja dengan kata lain pemerintahan dalam arti sempit tidak lain hanya pemerintah. Jadi dalam arti sempit, pemerintahan negara tidak meliputi kekuasaan perundang-undangan, peradilan dan polisi. Kekuasaan pemerintahan dalam arti sempit ini dikenal dengan istilah "bestuur". ${ }^{28}$

Sejak awal berdirinya Negara Kesatuan Republik Indonesia pada tanggal 17 Agustus 1945, para pendiri negara telah menjatuhkan pilihan pada prinsip pemencaran kekuasaan dalam penyelenggaraan pemerintahan negara Indonesia yang tujuannya jelas tercantum dalam alenia ke-4 Pembukaan Undang-Undang Dasar 1945 yang menegaskan bahwa “...melindungi segenap bangsa Indonesia dan seluruh tumpah darah Indonesia dan untuk memajukan kesejahteraan umum, mencerdasakan kehidupan bangsa, dan ikut melaksanakan ketertiban dunia yang berdasarkan kemerdekaan, perdamaian abadi dan keadilan sosial.

Untuk mencapai maksud tersebut maka para pejabat di daerah-daerah membantu penyelenggaraan pemerintahan pusat di daerah karena daerah Indonesia terbagi dalam daerah yang bersifat otonom atau bersifat daerah administrasi. Ada beberapa pengertian tentang pemerintahan daerah atau lokal yang dapat dirujuk dari beberapa pendapat berikut:

Pertama, G.M. Harris ${ }^{29}$ dalam bukunya Comparative Local Govern-ment mengatakan bahwa: "The term local government may have one of two meanings, it may signify: (1) the government of all part of a country by means of local agents appointed and responsible only to the central government. This is part of centralized system and my he called local state government. (2) Government by local baddies, feely elected wich while subjected to the supremacy of national government are endowed in some respect with power, discreation and responsibility, wich they can exercise without control cover their

\footnotetext{
${ }^{28}$ Pipin Syarifin dan Dedah Subaedah, Op. Cit., 2005, hlm. 65.

${ }^{29}$ G. M. Harris, Comparative Local Government dalam Martin Junung, Politik Lokal dan Pemerintahan Daerah dalam Perspektif Otonomi Daerah, Pustaka Nusatama, Yogyakarta, 2000.
} 
decision by the higher authority, this is called in many countries as communal autonomy".

Kedua, De Guman dan Tapales tidak mengajukan suatu batasan apapun tentang pemerintahan daerah, hanya mereka menyebutkan lima unsur pemerintahan lokal sebagai berikut: ${ }^{30} 1$. A local government is a political sub division of soverign nation or stat; 2. It is constituted by law; 3. It has governing body which is locally selected; 4 . Undertakes role making activities; dan 5. It perform service within its jurisdiction.

Ketiga, Josef Riwu Kaho ${ }^{31}$ mendefinisikan local government sebagai berikut: “Bagian dari pemerintah suatu negara atau bangsa yang berdaulat yang dibentuk secara politis berdasarkan undang-undang yang memiliki lembaga atau badan yang menjalankan pemerintahan yang dipilih masyarakat daerah tersebut, dan dilengkapi dengan kewenangan untuk membuat peraturan, memungut pajak serta memberikan pelayanan kepada warga yang ada di dalam wilayah kekuasaannya".

Dalam sejarahnya, di Indonesia pernah dikenal istilah daerah swatantra, yang sekarang ini dikenal dengan pemerintahan daerah. Pemerintahan umum pusat di daerah pada masa kemerdekaan disebut pamong praja, masa Belanda dipanggil dengan Binnenlandsbestuur, Bestuurdiants, pemerintahan pangreh, praja.

Pemerintahan khusus pusat di daerah disebut jawatan atau dinas pusat di daerah atau dinas vertikal. Jadi pemerintahan lokal tidak sama dengan pemerintahan daerah. Pemerintahan lokal meliputi pamong praja, jawatan vertikal dan pemerintahan daerah. ${ }^{32}$

Undang-Undang No. 32 Tahun 2004 mengartikan pemerintah daerah sebagai kepala daerah beserta perangkat daerah otonom yang lain sebagai badan eksekutif daerah. Daerah otonom menurut undang-undang ini adalah kesatuan masyarakat hukum yang mempunyai batas daerah tertentu berwenang mengatur dan mengurus kepentingan masyarakat setempat menurut prakarsa sendiri berdasarkan aspirasi masyarakat dalam ikatan negara Republik Indonesia.

Secara yuridis formal, landasan hukum dari penyelenggaraan pemerintahan daerah di Indonesia adalah Pasal 18 UUD 1945 yang mengamanatkan beberapa hal yaitu: ${ }^{33} 1$. Bahwa negara Republik Indonesia terdiri atas daerah propinsi, daerah

\footnotetext{
${ }^{30}$ Josef Riwu Kaho, Prospek otonomi Daerah di Negara RI, PT RajaGrafindo Persada, Jakarta, 1998, hlm. 43.

${ }^{31}$ Ibid., hlm. 67.

${ }^{32}$ Martin Jumung, Politik Lokal dan Pemerintah Daerah Dalam Perspektif Otonomi Daerah, Pustaka Nusantara, Jakarta, 2005, hlm. 41.

${ }^{33}$ Pipin Syarifin dan Dedah Subaedah, Hukum..., Op. Cit., hlm. 2.
} 
propinsi terdiri atas daerah kabupaten dan kota yang mempunyai pemerintahan daerah yang diatur dengan undang-undang; 2. Pemerintah daerah tersebut baik propinsi maupun kabupaten dan kota mengatur dan mengurus sendiri urusan pemerintahan menurut asas otonomi dan tugas pembantuan; dan 3. Susunan dan tata cara penyelenggaraan pemerintahan daerah diatur dalam undang-undang.

Untuk melaksanakan ketentuan mengenai pemerintahan daerah yang diatur dalam Pasal 18 UUD 1945 maka dibentuklah peraturan-peraturan yang terkait dengan pemerintahan daerah antara lain yaitu: ${ }^{34}$ a. Sebelum amandemen UUD 1945 dibentuk Undang-Undang No. 5 Tahun 1974 tentang Pokok-pokok Pemerintahan Daerah yang kemudian diganti dengan Undang-Undang No. 22 Tahun 1999 tentang Pemerintahan Daerah; b. Setelah amandemen UUD 1945 dibentuk Undang-Undang No. 32 Tahun 2004 tentang Pemerintahan Daerah sebagai pengganti Undang-Undang No. 22 Tahun 1999.

Dalam pelaksanaan otonomi, dikenal tiga bentuk asas dalam penyelenggaraan pemerintahan daerah yakni :

Pertama, Asas Desentralisasi. Desentralisasi sebagai suatu sistem yang dipakai dalam bidang pemerintahan merupakan kebalikan dari sentralisasi. Dalam sistem sentralisasi, kewenangan pemrintah baik dipusat maupun didaerah, dipusatkan dalam tangan pemerintah pusat. Pejabat-pejabat di daerah hanya melaksanakan kehendak pemerintah pusat. Dalam sistem desentralisasi, sebagian kewenangan pemerintah pusat dilimpahkan kepada pihak lain untuk dilaksanakan. ${ }^{35}$

Menurut Hans Kelsen, pengertian desentralisasi berkaitan dengan pengertian negara karena negara itu merupakan tatanan hukum (legal order), maka pengertian desentralisasi itu menyangkut berlakunya sistem tatanan hukum dalam suatu negara. Ada kaidah-kaidah hukum yang berlaku sah untuk seluruh wilayah negara yang disebut kaidah sentral (central norms) dan ada pula kaidah-kaidah hukum yang berlaku sah dalam bagian-bagian wilayah yang berbeda yang disebut desentral atau kaidah lokal (decentral or local norms). ${ }^{36}$ Jadi apabila berbicara tentang tatanan hukum yang desentralistik, maka hal ini akan dikaitkan dengan lingkungan (wilayah) tempat berlakunya tatanan hukum yang sah tersebut.

Kedua, Asas Dekonsentrasi. Penyelenggaraan pemerintahan daerah di Indonesia selain didasarkan pada asas desentralisasi juga didasarkan pada asas dekonsentrasi,

\footnotetext{
${ }^{34}$ Ibid., hlm. 10.

${ }^{35}$ Ibid., hlm. 45.

${ }^{36}$ Hans Kelsen, General Theory of Law and State, Russell \& Russell, New York, 1945, hlm. 303-304.
} 
hal ini dapat dilihat dari rumusan Pasal 18 ayat (5) UUD RI 1945 yang menyatakan bahwa pemerintah daerah menjalankan otonomi seluas-luasnya, kecuali urusan pemerintahan yang oleh undang-undang ditentukan sebagai urusan pemerintah pusat.

Urusan pemerintah pusat yang perlu diselenggarakan oleh perangkat pemerintah pusat sendiri, sebetulnya tercermin dalam pidato Soepomo di hadapan BPUPKI tanggal 31 Mei dengan mengatakan: ${ }^{37 ~ “ M a k a ~ d a l a m ~ n e g a r a ~ I n d o n e s i a ~ y a n g ~}$ berdasar pengertian negara integralistik itu, segala golongan rakyat, segala daerah yang mempunyai keistimewaan sendiri, akan mempunyai tempat dan kedudukan sendiri sebagai bagian organik dari negara seluruhnya. Soal pemerintahan apakah yang akan diurus oleh Pemerintah Pusat dan soal apakah yang akan diserahkan kepada Pemerintah Daerah, baik daerah besar maupun daerah kecil, itu semuanya tergantung dari pada "doellmatigheid" berhubungan dengan waktunya, tempat dan juga soalnya."

Dalam pengertian yang lain, Amrah Muslimin menafsirkan dekonsentrasi sebagai pelimpahan kewenangan dari pemerintah pusat kepada pejabat-pejabat bawahan dalam lingkungan administrasi sentral, yang menjalankan pemerintahan atas nama pemerintah pusat, seperti gubernur, walikota dan camat. Mereka melakukan tugasnya berdasarkan pelimpahan kewenangan dari pemerintah pusat pada alat-alat pemerintah pusat yang berada di daerah. ${ }^{38}$

Mengenai dekonsentrasi, Bagir Manan berpendapat bahwa dekonsentrasi sama sekali tidak mengandung arti bahwa dekonsentrasi adalah sesuatu yang tidak perlu atau kurang penting. Dekonsentrasi adalah mekanisme untuk menyelenggarakan urusan pusat di daerah. ${ }^{39}$ B. Hestu Cipto Handoyo \& Y.Thresianti memberikan tafsiran lain mengenai dekonsentrasi, menurutnya dekonsentrasi pada prinsipnya adalah $^{40} 1$. merupakan manifestasi dari penyelenggaraan pemerintahan negara yang mempergunakan asas sentralisasi; 2. menimbulkan wilayah-wilayah administratif yang tidak mempunyai urusan rumah tangga sendiri; 3. merupakan manifestasi dari penyelenggaraan tata laksana pemerintah pusat yang ada di daerah.

Ketiga, Asas Tugas Pembantuan. Daerah otonom selain melaksanakan asas desentralisasi juga dapat diserahi kewenangan untuk melaksanakan tugas pembantuan (medebewind). Tugas pembantuan dalam pemerintahan daerah adalah tugas untuk ikut

\footnotetext{
${ }^{37}$ Muhammad Yamin, Naskah Persiapan Undang-Undang Dasar 1945, Prapanca, Jakarta, 1959, hlm. 118.

${ }^{38}$ Amrah Muslimin, Op Cit., hlm. 35.

${ }^{39}$ Bagir Manan, Hubungan Antara Pusat dan Daerah Menurut UUD 1945, Armico, Bandung, 1995, hlm. 60.

${ }^{40}$ B. Hestu Cipto Handoyo \& Y. Thresianti, dalam Martin Jumung, 2005, Op. Cit., hlm. 92.
} 
melaksanakan peraturan perundang-undangan bukan saja yang ditetapkan oleh pemerintah pusat akan tetapi juga yang ditetapkan oleh pemerintah daerah tingkat atasnya. ${ }^{41}$ Menurut Irawan Soejito, tugas pembantuan itu dapat berupa tindakan mengatur (tugas legislatif) atau dapat pula berupa tugas eksekutif (beschikken). Daerah yang mendapat tugas pembantuan diwajibkan untuk mempertanggung jawabkan kepada yang menugaskan. ${ }^{42}$ Amrah Muslim menafsirkan tugas pembantuan (medebewind) adalah kewenangan pemerintah daerah menjalankan sendiri aturan-aturan dari pemerintah pusat atau pemerintah daerah yang lebih tinggi tingkatannya. ${ }^{43}$

Sementara itu, Bagir Manan mengatakan ${ }^{44}$ bahwa pada dasarnya tugas pembantuan adalah tugas melaksanakan peraturan perundang-undangan tingkat lebih tinggi (de uitvoering van hogere regelingen). Daerah terikat melaksanakan peraturan perundangundangan termasuk yang diperintahkan atau diminta (vorderen) dalam rangka tugas pembantuan. Tugas pembantuan dalam hal-hal tertentu dapat dijadikan semacam "terminal" menuju penyerahan penuh suatu urusan kepada daerah atau tugas pembantuan merupakan tahap awal sebagai persiapan menuju kepada penyerahan penuh. Bidang tugas pembantuan seharusnya bertolak dari : a. Tugas pembantuan adalah bagian dari desentralisasi dengan demikian seluruh pertanggungjawaban mengenai penyeleng-garaan tugas pembantuan adalah tanggung jawab daerah yang bersangkutan. b. Tidak ada perbedaan pokok antara otonomi dan tugas pembantuan. Dalam tugas pembantuan terkandung unsur otonomi (walaupun terbatas pada cara melaksanakan), karena itu daerah mempunyai kebebasan untuk menentukan sendiri cara-cara melaksanakan tugas pembantuan. c. Tugas pembantuan sama halnya dengan otonomi, mengandung unsur penyerahan (overdragen) bukan penugasan (opdragen). Perbedaannya, kalau otonomi adalah penyerahan penuh sedangkan tugas pembantuan adalah penyerahan tidak penuh. Menambahkan literatur yang ada, Sjachran Basah mengatakan bahwa tugas pembantuan (medebewind) adalah menjalankan ketentuan perundangundangan yang lebih tinggi tingkat derajatnya dari pihak lain secara bebas. ${ }^{45}$

Desentralisasi adalah praktik yang telah mendunia dan merupakan bagian dari strategi setiap institusi yang berkehendak untuk efisien dalam persaingan global.

\footnotetext{
${ }^{41}$ Prabawa Utama, Pemerintahan di Daerah, IND-HILL.CO, Jakarta, 1991, hlm. 13.

${ }^{42}$ Irawan Soejito, Hubungan Pemerintah Pusat dan Pemerintah Daerah, Bina Aksara, Jakarta, 1981, hlm. 117.

${ }^{43}$ Amrah Muslimin, Op. Cit, hlm. 8.

${ }^{44}$ Bagir Manan, Op. Cit., hlm. 179-181.

${ }^{45}$ Sjachran Basah, Eksistensi dan Tolok. Ukur Badan Peradilan Administrasi di Indonesia, cet ke-3, Alumni, Bandung, 1997, hlm. 31 .
} 
Demikian pula halnya dengan negara Kesatuan Republik Indonesia, di mana desentralisasi menjadi kewenangan dan terbagi menjadi bagian bagian yang terintegrasi dalam wadah Negara Kesatuan Republik Indonesia yang diharapkan bergerak secara efisien dan efektif sehingga dapat mengatasi tantangan global. Otonomi adalah derivat dari desentralisasi, oleh karena itu daerah otonom adalah daerah yang mandiri dalam berprakarsa. Tingkat kemandirian dan turunan dari tingkat desentralisasi yang diselenggarakan menunjukkan bahwa semakin tinggi derajat desentralisasi semakin tinggi pula tingkat otonomi daerah. ${ }^{46}$

Dari segi analisis hukum dengan diberlakukannya Undang Undang Nomor 32 Tahun 2004 dan Undang Undang Nomor 33 Tahun 2004, daerah mempunyai peluang besar untuk menjabarkannya dalam tatanan operasional. Undang undang tidak dapat dilaksanakan tanpa ada peraturan pelaksanaan. Dalam konteks ini otonomi daerah mempunyai arti kebebasan untuk melaksanakan pembangunan. Dengan kata lain daerah mempunyai peluang untuk merumuskan langkah langkah pembangunannya sejalan dengan kepentingan negara kesatuan serta tidak berbenturan dengan undang undang yang berlaku meliputi pengaturan atau perundang undangan sendiri, pelaksanaan sendiri. Dengan demikian daerah otonom adalah daerah yang berhak dan berkewajiban mengatur mengurus rumah tangganya sendiri. Salah satunya adalah pengelolaan keuangan daerah. ${ }^{47}$

Penyelenggaraan fungsi pemerintahan daerah akan terlaksana secara optimal jika penyelenggara urusan pemerintahan diikuti dengan pencarian sumber-sumber penerimaan yang cukup kepada daerah, dengan mengacu pada undang-undang tentang perimbangan keuangan antara pemerintah pusat dan pemerintah daerah yang besarnya disesuaikan dan diselaraskan dengan pembagian kewenangan antara pemerintah dan daerah. Hubungan antara keuangan negara dan keuangan daerah diuraikan sebagai berikut: ${ }^{48} 1$. Presiden selaku kepala pemerintahan memegang kekuasaan pengelolaan negara yang merupakan bagian kekuasaan pemerintah; 2. Presiden kemudian menyerahkan kekuasaan tersebut kepada kepala daerah (gubernur/bupati/walikota) selaku kepala pemerintahan daerah untuk mengelola keuangan daerahnya dan mewakili pemerintah daerah dalam pemilikan kekayaan yang terpisah; 3. Hubungan antara pusat dan daerah menyangkut hubungan

\footnotetext{
${ }^{46}$ Basuki, Pengelolaan Keuangan Daerah, Lembaga Administrasi Negara, Jakarta, 2008, hlm. 14.

${ }^{47}$ Ibid.

${ }^{48}$ Muhammad Djumhana, Op.Cit. hlm. 5.
} 
pengelolaan pendapatan (revenue) dan penggunaan (expenditure) baik untuk kepentingan pengeluaran rutin maupun pembangunan daerah dalam rangka memberikan pelayanan publik yang berkualitas, responsibel dan akuntabel; 4 . Konsep hubungan antara pusat dan daerah adalah hubungan administrasi dan hubungan kewilayahan. Hubungan tersebut diatur sedemikian rupa melalui kewajiban pemerintah pusat mengalokasikan dana perimbangan kepada pemerintah daerah. Sehingga, semua sumber keuangan yang melekat pada setiap urusan yang diserahkan ke daerah menjadi sumber keuangan daerah.

Dari keseluruhan uraian di atas penulis melihat bahwa hubungan antara pemerintah pusat dan pemerintah daerah dalam pengelolaan keuangan dapat ditinjau dari tiga aspek:

Pertama, dalam Tinjauan Yuridis. Pengelolaan Keuangan Negara di Indonesia didasarkan pada UU No. 17 Tahun 2003 dan dalam undang-undang ini secara tegas telah disebutkan bahwa salah satu ruang lingkup keuangan negara adalah keuangan daerah. Sebagai pelaksanaan dari hal ini maka ditetapkan PP No. 58 Tahun 2005 tentang Pengelolaan Keuangan Daerah. Secara yuridis dapat dikatakan bahwa hubungan pusat dan daerah dalam pengelolaan keuangan adalah pelaksanaan pengelolaan keuangan daerah didasarkan pada PP No. 58 Tahun 2005 sebagai pelaksanaan dari UU No. 17 Tahun 2003.

Kedua, secara Tinjauan Sistem Pemerintahan. Presiden merupakan kepala pemerintahan sekaligus merupakan pemegang kekuasaan pengelolaan keuangan negara. Dengan diterbitkannya UU No. 32 Tahun 2004 maka presiden mendelegasikan kekuasaannya kepada kepala daerah selaku kepala pemerintahan daerah dan salah satu kewenangan yang didelegasikan adalah kewenangan pengelolaan keuangan di daerahnya.

Ketiga, dalam Tinjauan Bentuk Negara. Indonesia adalah negara kesatuan. Ini adalah ketegasan konstitusi yang tidak bisa ditawar. Dalam konsepsi negara kesatuan, tidak ada pemisahan antara pemerintah pusat dan pemerintah daerah. Pendelegasian kewenangan kepada pemerintah daerah tidak berarti pemerintah pusat tidak melakukan pengawasan terhadap pelaksanaan pemerintahan daerah. Salah satu pengawasan yang dilakukan adalah dalam pengelolaan keuangan daerah. Otonomi daerah yang dilaksanakan seluas-luasnya tetap dalam kerangka negara kesatuan sehingga dalam hubungan pusat dan daerah dalam konsepsi ini adalah suatu hubungan pengawasan. 


\section{Penutup}

Otonomi daerah memberikan keleluasaan bagi daerah dalam rangka melakukan pengelolaan keuangan, namun demikian otonomi daerah ini tidak dilaksanakan dalam kerangka yang bertentangan dengan bentuk negara kesatuan dan sistem pemerintahan presidential sehingga dalam pengelolaan keuangan masih terdapat hubungan yang erat antara pemerintah pusat dan daerah karena pamerintah daerah merupakan penerima delegasi dari pemerintah pusat dan pemerintah pusat tetap harus melaksanakan pengawasan terhadap pengelolaan keuangan daerah agar pengelolaan yang dilaksanakan tetap berada dalam kerangka konstitusi tanpa memudarkan kemandirian daerah dalam melaksanakan pengelolaan keuangan.

\section{Daftar Pustaka}

Basah, Sjachran, Eksistensi dan Tolok Ukur Badan Peradilan Administrasi di Indonesia, cet ke-3, Alumni, Bandung, 1997.

Basuki, Pengelolaan Keuangan Daerah, Lembaga Administrasi Negara, Jakarta, 2008.

Djafar Saidi, Muhammad, Hukum Keuangan Negara, Rajawali Press, Jakarta, 2008.

Djumhana, Muhammad, Pengantar Hukum Keuangan Daerah, Citra Aditya Bhakti, Bandung, 2007.

Gde Artjana, I, “Upaya Membangun Akuntabilitas Pengelolaan Dan Pertanggungjawaban Keuangan Negara Di Lingkungan Militer Menuju Terciptanya Good Governance Tantangan Dan Harapan", dipaparkan dalam FGD SSR Propatria, tanggal 27 Februari 2007.

Ghandi, L.M. Harmonisasi Hukum Menuju Hukum Responsif, Pidato Pengukuhan Jabatan Guru Besar Tetap pada Fakultas Hukum Universitas Indonesia, Jakarta, 1995.

Jumung, Martin, Politik Lokal dan Pemerintahan Daerah dalam PerspektifOtonomi Daerah, Pustaka Nusatama, Yogyakarta, 2005.

Kencana Syafii, Inu, Sistem Pemerintahan Indonesia, Rineka Cipta, Jakarta, 2002.

Kelsen, Hans, General Theory of Law and State, Russell \& Russell, New York, 1945.

Liang Gie, The, Pertumbuhan Pemerintahan Daerah di Negara Republik Indonesia, Liberty, Yogyakarta, 1993.

Muslimin, Amrah, Aspek-Aspek Otonomi Daerah, Alumni, Bandung, 1986.

Manan, Bagir dan Kuntana Magnar, Peranan Peraturan Perundang-Undangan dalam Pembinaan Hukum Nasional, Armico, Bandung. 1997. 
Manan, Bagir, Hubungan Antara Pusat dan Daerah Menurut UUD 1945, Armico, Bandung, 1995.

P. Soeria Atmadja, Arifin, tanpa tahun, “Hukum Keuangan Negara Pasca 60 Tahun Indonesia Merdeka", www. Pemantauperadilan.com, akses tanggal 2 Desember 2009.

Perdana Wiratraman, Herlambang, Badan Pemeriksa Keuangan dan Pertanggungjawaban Keuangan Negara, Departemen Hukum Tata Negara Fakultas Hukum Universitas Airlangga, Surabaya, 2008.

Riawan Tjandra, W., Hukum Keuangan Negara, PT Grasindo, Jakarta, 2006.

Riwu Kaho, Josef, Prospek otonomi Daerah di Negara RI, PT Raja Grafindo Persada, Jakarta, 1998. Syarifin, Pipin dan Dedah Subaedah, Hukum Pemerintahan Daerah, Pustaka Bani Quraisy, Bandung, 2005.

Soejito, Irawan, Hubungan Pemerintah Pusat dan Pemerintah Daerah, Bina Aksara, Jakarta, 1981.

Syarifin, Pipin dan Dedah Subaedah, Hukum Pemerintahan Daerah, Pustaka Bani Quraisy, Bandung, 2005.

Utama, Prabawa, Pemerintahan di Daerah, IND-HILL.CO, Jakarta, 1991.

Utrecht, Pengantar Hukum Indonesia, Ichtiar Baru, Jakarta, 1986.

Yamin, Muhammad, Proklamasi dan Konstitusi, Ghalia Indonesia, Jakarta, 1982. 